\section{Alternative Medicine:} The Definitive Guide, compiled by the Burton Goldberg Group ( 1,068 pages, July 1994), is a reasonably thorough summary of nearly every Western and Eastern system of treatment outside of conventional medicine. Goldberg, an American businessman, marshalled the writers and consultants who contributed to this volume. He cautions that although many of these techniques are helpful for such common ailments as asthma, gastrointestinal disorders, headaches, and sinusitis (and may even prove useful in treating cancer, heart disease, or arthritis), they are no substitute for the advice and care of a physician or other licensed health professional. Part One is an essay on the causes of disease and the politics of health care. Part Two explains how alternative therapies work, from acupuncture to yoga, and how to self-administer them or locate a qualified practitioner. Part Three reviews more than 175 health conditions and the best self-care and professional treatments that deal with them. \$59.95. Future Medicine Publishing, Inc., 10124 18th St. Ct. East, Puyallup, WA 98371. ISBN 0-9636334-3-0.

The Basque Language, by Alan R. King ( 462 pages, August 1994), is the first practical introduction to Basque for English-speaking audiences. In adclition to 40 carefully prepared, lesson-like units, the text offers a comprehensive reference grammar section and an elementary reader with selections on Basque geography, language, folklore, modern literature, and newspaper excerpts. The book also includes EnglishBasque and Basque-English vocabulary lists and three indexes that cover grammatical concepts, Basque affixes, and English phrases. \$60.00. University of Nevada Press, Reno, NV 895570076. ISBN 0-87417-155-5.

\section{The Beinecke Lesser Antilles Collection} at Hamilton College: A Catalogue of Books, Manuscripts, Prints, Maps, and Drawings, 1521-1860, prepared by Samuel J. Hough and Penelope R. O. Hough (414 pages, October 1994), provides extensive descriptions of 2,000 books and manuscripts that Walter Beinecke Jr. collected over several decades and donated to Hamilton College in Clinton, New York. A 68page index enhances access. $\$ 150.00$. University Press of Florida, 15 N.W. 15th St., Gainesville, FL 32611-2079. ISBN 0-8130-1292-9.

\section{Biographical Dictionary} of North American Classicists, edited by Ward W. Briggs Jr. (800 pages, September 1994), contains 600 profiles of scholars who significantly influenced the course of Classical studies in the United States and Canada. In addition to vital statistics and publication lists, individual contributors have written a paragraph or two about each classicist's career. $\$ 115.00$. Greenwood Press, 88 Post Road West, Westport, CT 06881-5007. ISBN 0-313-24560-6.

\section{Culfural Crusaders: Women Librarians} in the American West, 1900-1917, by Joanne E. Passet (248 pages, November 1994), documents the lives of several hundred women who participated in the development and diffusion of the library in the American West in the first two decades of the 20th century. The author focuses on women librarians in the eleven states west of the 100th meridian: their education, their impressions of the West, their changing personal and professional aspirations, their family relationships, and their advancement of librarianship on the frontier. A final chapter presents brief biographies of four representative women who embodied the spirit of these cultural crusaders. With 36 historical photos. $\$ 40.00$. University of New Mexico Press, 1720 Lomas Blvd. N.E., Allbuquerque, NM 87131-1591. ISBN 08263-1530-5.

Early American Cinema, by Anthony Slide (263 pages, rev. ed., 1994), is a concise history of the American movie industry before 1920 . Topics include early independent filmmaking, the birth of the feature film, the star system, the role of women in film, and new technologies. Completely revised since the first edition of 1970. \$39.50. Scarecrow Press, 52 Liberty St. Metuchen, NJ 08840. ISBN 0-8108-2711-5. 
Herbs, by Lesley Bremness (304 pages, 1994), is a visual guide to more than 700 herb species worldwide with a summary of each plant's uses in medicine, cookery, perfumery, and homeopathy. The photography is impressive, showing whatever parts are essential (roots, stems, flowers, fruit) as well as a view of the full tree, shrub, plant, or vine. The scholarship is impeccable. For example, how many people know this: the root bark oil of sassafras (safrole), once used in root beer but now "banned in the USA, is only one-fourteenth as carcinogenic as the ethanol in ordinary beer." This volume is one in a series of "Eyewitness Handbooks" that are essential for natural history collections. Others include rocks and minerals, butterflies and moths, trees, fossils, cats, dogs, horses, birds of the world, aquarium fish, and birds' eggs. The herb volume is $\$ 29.95$ hardback. Dorling Kindersley Publishing, Inc., 232 Madison Ave., New York, NY 10016. ISBN 1-56458-497-6.

A good supplement to this volume is Herbs of Choice: The Therapeutic Use of Phytomedicinals, by Varro E. Tyler (209 pages, October 1994), which attempts to separate fact from folklore in the medicinal properties of herbs. \$24.95 hardback. Haworth Press, $10 \mathrm{Al}$ ice Street, Binghamton, NY 13904. ISBN 156024-894-7.

\section{Encyclopedia of American Indian Cos-} tume, by Josephine Paterek ( 516 pages, May 1994), summarizes what is known about the dress, hairstyles, armor, body paint, tattoos, and masks of Native American and Inuit tribal groups. Supplemented with photographs and drawings, this comprehensive work distinguishes the Chinook from the Chippewa. \$75.00. ABC-CLIO, Inc., P.O. Box 1911, Santa Barbara, CA 93116-1911. ISBN 0-87436-685-2.

\section{Clarification}

In the ACRL Annual Report in the November issue of CERL News, the program "Beyond the F1 Key: Thinking and Teaching the Internet within the Curriculum" was mistakenly listed as having been solely sponsored by the Bibliographic Instruction Section. The College Libraries Section cosponsored the program. The editors regret the error.
In Hitler's Shadow, by Yaron Svoray and Nick Taylor (275 pages, October 1994), is the story of Svoray, an Israeli Jew, infiltrating the German neo-Nazi underground, a network of skinheads and Old Guard that is perhaps more widespread and dangerous than Americans realize. In the course of his investigation he came across evidence of paramilitary training camps that sent neo-Nazi soldiers to support Croatian soldiers in the former Yugoslavia. The silence of the German media and the federal government on this movement, at least prior to Svoray's revelations, is eerie. Merely a creepy minority, you say? So were the National Socialists in 1923 at the time of the Putsch. \$24.95. Doubleday, 1540 Broadway, New York, NY 10036. ISBN 0385-47284-6.

Libraries and Librarianship in Korea, by Pongsoon Lee and Young Ai Um (172 pages, September 1994), reviews the development of national, academic, public, special, and school libraries in South Korea since the 1950s, \$55.00. Greenwood Press, 88 Post Road West, Westport, CT 06881. ISBN 0-313-28743-0.

\section{Management and Organization of the} Acquisitions Department, edited by Twyla Racz and Rosina Tammany (131 pages, November 1994), addresses some timely topics in acquisitions work: budget cuts as a catalyst for change, staffing, copy cataloging in acquisitions, nonperiodical continuations, and e-journals. Published simultaneously as no. 12 of The Acquisitions Librarian. \$24.95. Haworth Press, 10 Alice St., Binghamton, NY 13904. ISBN 1-56024583-2.

Records Management Handbook, by Ira A. Penn, Gail Pennix, and Jim Coulson (303 pages, 2d ed., September 1994), presents proven management strategies for developing, implementing, and operating a records management program. Topics include management analysis, records appraisal, forms and directives, records disposition, and the highs and lows of using technology. \$64.95. Gower; distributed by Ashgate Publishing Co., Old Post Road, Brookfield, VT 05036. ISBN 0-566-07510-5.

\section{The Refiner's Fire: The Making of Mor- mon Cosmology, 1644-1844, by John L.} Brooke (421 pages, September 1994), documents the similarities between the early doctrines of Mormonism in the 1830s (the coequal- 
ity of matter and spirit, the covenant of celestial marriage, the goal of human godhood) with European hermetic and alchemical traditions drawn from the ancient world and fused with Christianity in the Renaissance. After Joseph Smith's death in 1844, Mormonism moved away from its occult origins and towards a more traditional Protestant Christianity. An insightful contribution to the controversy surrounding the origins of Mormonism. \$34.95. Cambridge University Press, 40 W. 20th St., New York, NY 10011-4211. ISBN 0-521-34545-6.

\section{Scholars' Guide to Washington, D.C.,} for Russian, Central Eurasian, and Baltic Studies, by Steven A. Grant and William E. Pomeranz (293 pages, 3rd ed., October 1994), surveys 750 collections, organizations, and agencies devoted to the regions of the former Soviet Union. Information in each section varies according to the type of organization or agency. There are indexes to personal papers, library subject strength, subjects, and organizations. $\$ 60.00$ hardcover. Johns Hopkins University Press, 2715 N. Charles St., Baltimore, MD 21218-4319. ISBN 0-943875-51-X.

\section{The Vampire Book: The Encyclopedia of} the Undead, by J. Gordon Melton ( 852 pages, October 1994). If you only have one vampire book in your reference collection, this should be it. Scholarly, comprehensive, and entertaining, this volume examines vampire lore from the early Middle Ages to Anne Rice. Melton, a renowned expert on cults and comparative religion, is equally at home in this commentary on horror, which ranges from Vlad the Impaler and vampirism in film and fiction to blood fetishes and the postmodern gothic subculture. Entries on garlic, sunlight, hypnotic powers, bats, fire, fingernails, the crucifix, spiders, and stakes will have you mesmerized. Even Count Chocula comes under consideration. With the most comprehensive listing of vampire films, plays, novels, organizations, and periodicals in existence, this book will bite your budget for a mere \$16.95. Visible Ink Press, 835 Penobscot Bldg., Detroit, MI 48226-4094. ISBN 0-81032295-1.

\section{Warblers of the Americas: An Identifi-} cation Guide, by Jon Curson, David Quinn, and David Beadle (252 pages, August 1994), is the first comprehensive guide to all 116 species of wood warblers (subfamily Parulinae) in

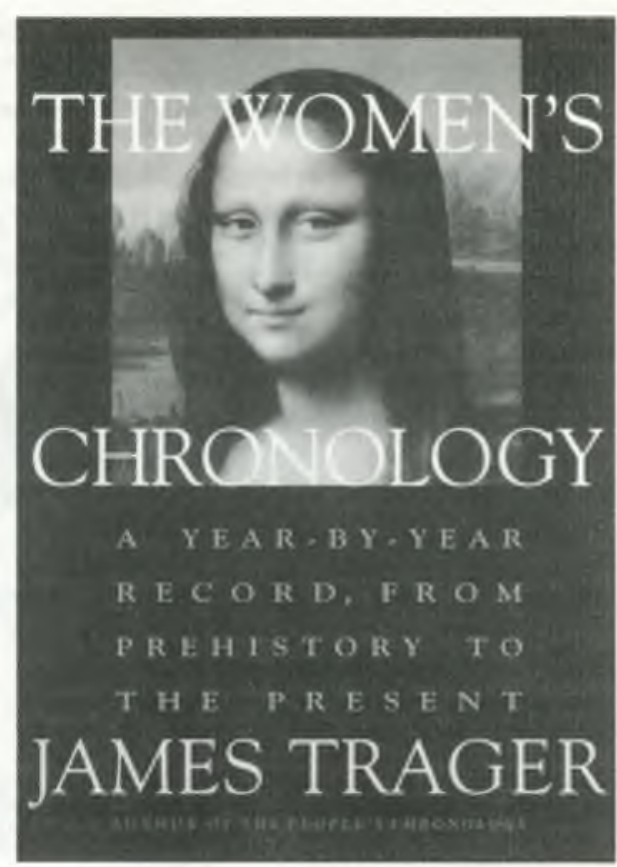

the Western Hemisphere; 36 full-color plates depict all the plumage variations. The text gives each warbler's identifying features, geographical variations, calls, habitat and habits, breeding, status and distribution, skull, movements, moult, and measurements. This is an essential book for taxonomy collections and a fun one for warbler watchers, especially those who venture to the Caribbean and other places where lesser-known species flourish. $\$ 40.00$. Houghton Mifflin Co., 215 Park Ave. South, New York, NY 10003. ISBN 0-395-70998-9.

The Women's Chronology, by James Trager (787 pages, September 1994), complements the author's massive The People's Chronology (recently updated through 1993 as a trade paperback) by highlighting the achievements, travails, trials, discoveries, and talents of women from prehistory to 1993. This is another mindboggling Trager reference triumph that brings history to life. Events are identified by symbols for political events, human rights, exploration, science, music, theater, food and drink, the environment, and many other topics. A very useful index and illustrations enhance the value of this indispensable work. \$19.95. Henry Holt Reference Books, $115 \mathrm{~W}$. 18 th St., New York, NY 10011. ISIBN 0-80503134-0. 


\section{Will you be ready for 2000 ?}

You will be when you learn, update, or refresh your skills at these Association for Library Collections \& Technical Services regional institutes

and preconferences in 1995.

\section{ACCESS TO MATERIALS IS MORE IMPORTANT THAN EVER!}

\section{BUILD YOUR COLLECTIONS}

\section{Collection Management \&}

Development

Major issues in the planning, development, and management of research library collections

July 27-29-Wellesley, Massachusetts.

\section{Business of Acquisitions}

Basic acquisitions processes, including monographs, serials, and other library resources

June 22-23 - Preconference to the ALA Annual Conference, Chicago, Illinois

\section{MANAGE YOUR WORK}

Technical Services Workstations: The State of the Art in Cataloging

Development of technical services workstations, a technology which brings all the tools for cataloging together online

March 17 - Atlanta, Georgia

(cosponsored by SOLINET)

March 20 - Dallas, Texas

(cosponsored by AMIGOS)

May I - Pomona, California

(cosponsored by PACNET)

September 29 - Minneapolis, Minnesota (cosponsored by MINITEX)

\section{FIND WHAT'S IN YOUR COLLECTIONS}

\section{Demystifying Subject Cataloging}

Fundamental subject cataloging principles from analyzing subject content to exploring $L C$ subject headings

April 2-3 - Minneapolis, Minnesota

October 24-25 - Preconference to the New York State Library Association conference in Rochester, New York

\section{Serials Cataloging in the Age of} Format Integration

Creation, interpretation, content, format, and uses of serials cataloging records

April 7-8 - Atlanta, Georgia

October 6-7 - San Francisco, Califomia

\section{AACR2000}

Rationale behind the principles of AACR2 and a vision of how the rules should be restructured for the year 2000 and beyond June 22 - Preconference to the ALA Annual Conference, Chicago, Illinois

\section{Interactive Multimedia Cataloging}

Applying the new Interactive Multimedia Guidelines and introduction to interactive multimedia technology, products and cataloging issues

June 23 - Preconference to the ALA Annual Conference, Chicago, Illinois

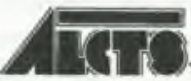

Reduced registration fees are a benefit of ALCTS membership!

For membership information, call Karen Whitclesey at 800-545-2433 ext. 5034; for institute or preconference registration information, contact Yvonne McLean at 800-545-2433 ext. 5032. 